ORIGINAL ARTICLE

\title{
Dominant amphipods of Posidonia oceanica seagrass meadows display considerable trophic diversity
}

\author{
Loïc N. Michel ${ }^{1,2}$, Patrick Dauby ${ }^{2}$, Sylvie Gobert ${ }^{1}$, Martin Graeve ${ }^{3}$, Fabienne Nyssen ${ }^{2}$, Nicolas Thelen ${ }^{4}$ \\ \& Gilles Lepoint ${ }^{1}$ \\ 1 Laboratory of Oceanology, Department of Biology, Ecology and Evolution, University of Liège, Liège, Belgium \\ 2 Laboratory of Systematics and Animal Diversity, Department of Biology, Ecology and Evolution, University of Liège, Liège, Belgium \\ 3 Marine Chemistry Division, Alfred Wegener Institute Helmholtz Centre for Polar and Marine Research, Bremerhaven, Germany \\ 4 Laboratory of Cellular and Tissular Biology, GIGA-Neurosciences, University of Liège, Liège, Belgium
}

\section{Keywords}

Epiphytes; fatty acids; mesograzers; seagrass;

SIAR; stable isotopes.

\author{
Correspondence \\ Loï N. Michel, Laboratory of Oceanology, \\ University of Liège, Institute of Chemistry \\ (B6C), 13 Allée du VI Août, B-4000 Liège, \\ Belgium. \\ E-mail: loicnmichel@gmail.com
}

Accepted: 24 June 2014

doi: 10.1111/maec.12194

\begin{abstract}
Gut content examination and trophic markers (fatty acids, stable isotopes of $\mathrm{C}$ and $\mathrm{N}$ ) were combined to delineate the diet of the dominant species of amphipods from Mediterranean Posidonia oceanica seagrass meadows and to highlight trophic diversity among this community. Our results indicate that, although all dominant species heavily relied on macroalgal epiphytes, considerable interspecific dietary differences existed. Carbon stable isotope ratios notably showed that some of the amphipod species favored grazing on epiphytes from leaves or litter fragments (Apherusa chiereghinii, Aora spinicornis, Gammarus aequicauda), while others such as Dexamine spiniventris preferred epiphytes from rhizomes. The remaining amphipods (Caprella acanthifera, Ampithoe helleri and Gammarella fucicola) readily consumed both groups. In addition, SIAR modeling suggested that most species had a mixed diet, and relied on several food items. Fatty acid analysis and gut contents revealed that contributions of microepiphytic diatoms and of benthic and suspended particulate organic matter to the diet of amphipods were anecdotal. None of the examined species seemed to graze on their seagrass host [low 18:2(n-6) and 18:3(n-3) fatty acids contents], but Gammarus aequicauda partly relied on seagrass leaf detritus, as demonstrated by the lesser ${ }^{13} \mathrm{C}$-depletion of their tissues. Overall, our findings suggest that amphipods, because of their importance in the transfer of organic matter from primary producers and detritus to higher rank consumers, are key items in $P$. oceanica-associated food webs.
\end{abstract}

\section{Introduction}

The Neptune grass, Posidonia oceanica (L.) Delile, 1813, is the most widespread seagrass of the Mediterranean Sea. This foundation species grows from the surface to depths of $45 \mathrm{~m}$, and is able to form large, typically monospecific meadows. These meadows play a key role in Mediterranean coastal areas, and are of crucial ecological importance. Their complex tridimensional structure offers a suitable habitat to hundreds of animal and plant species, as well as micro-organisms (Buia et al. 2000). In addi- tion, through the epiphytes that grow on all parts of the plants, its dead and decaying tissues and, to a lesser extent, its living tissues, P. oceanica supports elaborate food webs (Vizzini 2009). As a result, P. oceanica meadows are biodiversity hotspots in the Mediterranean.

In $P$. oceanica meadows, amphipods are one of the dominant groups of vagile mesoinvertebrates (i.e. animals whose size exceeds that of an average copepod but are smaller than $2.5 \mathrm{~cm}$ ), forming an abundant and diverse taxocenosis (Gambi et al. 1992). In most seagrass systems, vagile mesoinvertebrates are regarded as key ecosystem 
components, notably because of their importance in food webs. Most of them are primary consumers and/or detritivores, therefore constituting a trophic link between producers and higher rank consumers. In addition, they frequently graze on seagrass tissues and/or epiphytes growing on the plants. In doing so, these meso-grazers can have strong direct and indirect effects on the functioning of seagrass meadow ecosystems (Jernakoff et al. 1996; Valentine \& Duffy 2006). The understanding of the trophic position of amphipods of $P$. oceanica meadows is nevertheless still poor.

In literature, they are traditionally regarded as generalist herbivores or herbivores/deposit feeders, mainly consuming leaves' plant epiphytes (diatoms and macroalgae) and associated detritus. However, these assumptions are rarely based on precise and adequate information. Instead, in many cases, they are considered to feed in these ways by analogy with other, better-known seagrass systems or animal groups (Kikuchi 1980; Mazzella et al. 1992); because they are sampled in association with seagrass epiphytes (Chimenz et al. 1989); or through literature reviews and feeding behavior observations (Gambi et al. 1992). These views are of course sensible and plausible, but accurate studies supporting them are rare, and the lack of actual diet data (gut contents, etc.) unfortunately limits the insights that can be drawn from them. Direct studies using stable isotopes of $\mathrm{C}$ and $\mathrm{N}$ have confirmed the importance of epiphyte-derived organic matter in the diets of amphipods from P. oceanica meadows (Lepoint et al. 2000; Vizzini et al. 2002). However, in these studies, amphipods were considered as a single group, without species distinction. Their data sets are therefore not suitable for the investigation of trophic diversity among amphipods.

Overall, information about the trophic ecology of amphipods from $P$. oceanica meadows seems to be partial and limited. As a result, it is hard to estimate the real importance of amphipods in P. oceanica-associated food webs. It is also difficult to assess whether their trophic activity has functional impacts on other parts of the meadow ecosystem. In this context, the main objectives of our study were (i) to delineate the diet of the most abundant species of the community and estimate the importance of food sources other than leaf epiflora $(P$. oceanica leaves and litter, suspended and benthic particulate organic matter, epifauna of leaves and litter fragments, and epiflora of litter fragments and rhizomes) for amphipod nutrition and (ii) to assess interspecific resource partitioning, as this phenomenon could be important in interactions among amphipod taxa, and notably in the limitation of competition for food.

To achieve these goals, amphipods and food sources were sampled at multiple events scattered over different periods of the year. Studying the diet of invertebrate consumers in environments featuring multiple producers can be a complicated task, and 'traditional' techniques (gut content examination) were therefore combined with the use of trophic markers. Here, $\mathrm{C}$ and $\mathrm{N}$ stable isotope ratios as well as fatty acid analysis were used. These trophic markers are among the most widely used, and their joint use has already proven to be efficient in the study of invertebrate trophic ecology in other seagrass meadows (Kharlamenko et al. 2001; Jaschinski et al. 2008; Lebreton et al. 2011).

\section{Material and Methods}

\section{Sampling}

All sampling was undertaken by scuba diving in Calvi Bay (Corsica, NW Mediterranean), in the surroundings of the STARESO research station (University of Liège). Posidonia oceanica meadows cover about $50 \%$ of the area of this bay, and reach depths of nearly $40 \mathrm{~m}$ (Bay 1984). The meadows of Calvi Bay show, in most places, a continuous extension, are relatively dense, and show an important foliar biomass and production (Bay 1984). All samples were taken within a distance of a few meters from the center of a permanent sampling site set up in a continuous meadow zone, at a depth of $10 \mathrm{~m}$ (center coordinates: $42^{\circ} 34^{\prime} 47^{\prime \prime} \mathrm{N}, 8^{\circ} 43^{\prime} 30^{\prime \prime} \mathrm{E}$ ).

Seven amphipod species were considered: Apherusa chiereghinii Giordani-Soika, 1949; Aora spinicornis Afonso, 1976; Dexamine spiniventris (Costa, 1853); Ampithoe helleri Karaman, 1975; Caprella acanthifera Leach, 1814; Gammarella fucicola (Leach, 1814) and Gammarus aequicauda (Martynov, 1931). The cumulative abundances of these species account for over $70 \%$ of the total amphipod density at the study site (Michel 2011). Putative food items included living $P$. oceanica leaves, fragments of dead $P$. oceanica leaves (litter), suspended particulate organic matter (SPOM), benthic particulate organic matter (BPOM) and epiphytic organisms growing on leaves, rhizomes and litter fragments of $P$. oceanica. In nearly all cases, a distinction was made between animal (epifauna) and plant (epiflora) epiphytes.

To ensure a sufficient collection of amphipods, three sampling methods were combined. First, a hand-towed net was used, following the methodology of Michel et al. (2010). Second, litter fragments present among the meadow (between the shoots) were handpicked to obtain the vagile organisms trapped between the fragments. Third, light traps, which were modified after those described by Michel et al. (2010), were used. After collection, amphipods were euthanized by freezing, identified to species level using a binocular microscope and then 
processed for gut content, stable isotope or fatty acid analysis (see below).

Posidonia oceanica shoots were manually uprooted, and litter fragments were handpicked. Leaves and litter fragments were scraped using a scalpel blade, and their animal and plant epiphytes were sorted under a binocular microscope. All the scraped leaves of each shoot were processed as a single sample. For litter, c. $10 \mathrm{~g}$ (wet mass) of scraped fragments were pooled and considered as a unique sample. Rhizome epiflora was separated from the shoots using fine scissors. BPOM was sampled by collecting the first centimetre of sediment between P. oceanica shoots, using a plastic container. Sediment was then sieved to eliminate the coarser debris $(>1 \mathrm{~cm})$. Seawater for SPOM sampling was collected in the meadow, among the leaves, using 2.5-l Niskin bottles. Seawater was then pre-sieved to remove items larger than $1 \mathrm{~cm}$, and filtered on pre-combusted $(4 \mathrm{~h}$ at $400{ }^{\circ} \mathrm{C}$ ) glass fiber filters (Whatman GF/F, sieve size $0.7 \mu \mathrm{m})$ until clogging.

\section{Gut content examination}

Amphipod specimens used for gut content examination were sampled during three campaigns: from 4 to 13 November 2007, from 6 to 15 March 2008 and from 30 May to 11 June 2008. Sampled animals were fixed in a formaldehyde solution ( $4 \%$ in seawater), and subsequently transferred to $70 \%$ ethanol for long-term preservation. Twenty well-preserved individuals were selected for each species. Animals were prepared following the methodology of Guerra-Garcia \& Tierna de Figueroa (2009). This technique, which has been proven to be efficient on a number of terrestrial and aquatic insects and crustaceans, involves body wall discoloration using Hertwig's liquid. After discoloration, gut content can be observed throughout the tissues of the entire animal. Each amphipod was placed in a vial containing $2 \mathrm{ml} \mathrm{Her-}$ twig's liquid. The vials were placed in an oven and maintained at $60{ }^{\circ} \mathrm{C}$ for $7-10$ days to achieve suitable discoloration. Once transparent, amphipods were mounted in toto on microscopic slides, using Hoyer's medium. Slides were photographed at $100 \times$ (for measurement of the total area of the gut content) and $400 \times$ or $1000 \times$ (to identify and precisely measure the surface of food items) magnifications. Photographs were taken using an Olympus BX50 microscope, an XC50 Camera and CELLB software (Olympus Europa GmBH, Hamburg, Germany), while measurements were performed using AXIOVISION software (Carl Zeiss MicroImaging GmBH, Göttingen, Germany). The surface occupied by each food item was expressed using relative units, as a percentage of the total area occupied by the gut contents.

\section{Fatty acid analyses}

Samples were taken during three different time periods: from 5 to 15 November 2008, from 2 to 14 March 2009 and from 14 to 29 July 2009. Because of the low biomass and lipid content of amphipods, two to 40 individuals had to be pooled for fatty acid analysis, depending upon the species (Table 1). After collection, samples were prepared following the method of Graeve et al. (2001). Total lipids were extracted using a mixture of dichloromethane and methanol 2:1 by vol., and fatty acids were converted to their fatty acid methyl ester (FAME) equivalents by trans-esterification. Tricosanoic acid methyl ester (23:0) was used as an internal standard for these preparation steps. FAMEs were analysed using gas chromatography at the Alfred Wegener Institute for Polar and Marine Research (AWI, Bremerhaven, Germany). The analysis was carried out with a Hewlett-Packard 6890 gas chromatograph equipped with a DB-FFAP fused silica capillary column $(30 \mathrm{~m} \times 0.25 \mathrm{~mm}$ inner diameter; $0.25 \mu \mathrm{m}$ film thickness), using temperature programming (160$240{ }^{\circ} \mathrm{C}$ at $4{ }^{\circ} \mathrm{C}$ per min, hold $\left.15 \mathrm{~min}\right)$. Fatty acids were identified by comparing retention times with those of commercial (Supelco 37 Component FAME Mix) and natural lab standards (mix of arctic copepods) of known composition. If necessary, identification was checked using a HP 5973 gas chromatography - mass spectrometry system. Relative concentrations of each detected fatty acid were computed using the area of their corresponding peaks on the output chromatograph, and were expressed as a percentage of the total fatty acids present in the tissues.

In order to investigate relationships between relative fatty acid compositions of amphipods, a bidimensional ordination based on non-metric multi-dimensional scaling (MDS) was performed using PRIMER 6.0 (PRIMER-

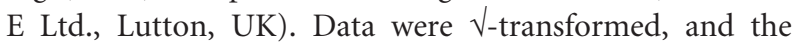
resemblance matrix was built using Bray-Curtis similarity coefficients. PRIMER 6.0 was also used to run one-way SIMPER (SIMilarity PERcentage) analysis on standardized, $\sqrt{ }$-transformed relative fatty acid compositions of amphipods, in order to identify the compounds that were the most useful in explaining resemblance or dissimilarity among amphipods.

\section{Stable isotope ratio measurements}

Samples were taken during four different time periods: from 30 May to 11 June 2008, from 5 to 15 November 2008, from 2 to 14 March 2009 and from 14 to 29 July 2009. Because of their low biomass, amphipods had to be pooled for $\mathrm{N}$ stable isotope ratio measurements, while $\mathrm{C}$ stable isotope ratios were able to be analysed on single individuals. The pooling strategy and the number of 
Table 1. Numbers of samples analysed for fatty acids and stable isotopes of carbon and nitrogen. Column numbers indicate the sampling periods (1: 30 May to 11 June 2008, 2: 5 to 15 November 2008, 3: 2 to 14 March 2009, 4: 14 to 29 July 2009). For amphipods, values in parentheses are the numbers of individuals pooled for each measurement.

\begin{tabular}{|c|c|c|c|c|c|c|c|c|c|c|c|}
\hline \multirow[b]{3}{*}{ Item } & \multirow{2}{*}{\multicolumn{3}{|c|}{ Fatty acids }} & \multicolumn{8}{|c|}{ Stable isotope ratios } \\
\hline & & & & \multicolumn{4}{|l|}{ Nitrogen } & \multicolumn{4}{|c|}{ Carbon } \\
\hline & 2 & 3 & 4 & 1 & 2 & 3 & 4 & 1 & 2 & 3 & 4 \\
\hline Apherusa chiereghinii & $2(30)$ & $2(30)$ & $6(30)$ & $10(20)$ & $10(20)$ & $10(20)$ & $10(20)$ & 20 & 20 & 20 & 20 \\
\hline Aora spinicornis & - & $1(20)$ & $4(20)$ & $8(15)$ & $8(15)$ & $7(15)$ & $9(15)$ & 20 & 20 & 20 & 20 \\
\hline Dexamine spiniventris & $1(3)$ & $1(3)$ & $9(3)$ & $10(3)$ & $10(3)$ & $10(3)$ & $10(3)$ & 20 & 20 & 20 & 20 \\
\hline Ampithoe helleri & $1(35)$ & - & - & $5(20)$ & $6(20)$ & $6(20)$ & $8(20)$ & 20 & 20 & 20 & 20 \\
\hline Caprella acanthifera & - & - & $1(40)$ & $5(20)$ & $5(20)$ & $5(20)$ & $7(20)$ & 20 & 20 & 20 & 20 \\
\hline Gammarella fucicola & - & $1(4)$ & - & $7(3)$ & $6(3)$ & $9(3)$ & $10(3)$ & 20 & 20 & 20 & 20 \\
\hline Gammarus aequicauda & $2(2)$ & $2(2)$ & $4(2)$ & $10(2)$ & $10(2)$ & $10(2)$ & $10(2)$ & 20 & 20 & 20 & 20 \\
\hline Posidonia oceanica leaves & 3 & 3 & - & 15 & 15 & 15 & 15 & 15 & 15 & 15 & 15 \\
\hline Posidonia oceanica litter & 3 & 3 & - & 15 & 15 & 15 & 15 & 15 & 15 & 15 & 15 \\
\hline Leaf epifauna & - & - & 2 & 7 & 6 & 7 & 11 & 7 & 6 & 7 & 11 \\
\hline Leaf epiflora & - & - & 7 & 9 & 8 & 9 & 12 & 9 & 8 & 9 & 12 \\
\hline Litter epifauna & - & - & $2^{a}$ & 6 & 5 & 7 & 7 & 6 & 5 & 7 & 7 \\
\hline Litter epiflora & - & - & & 7 & 6 & 7 & 8 & 7 & 6 & 7 & 8 \\
\hline Rhizome epiflora & - & 1 & 4 & 10 & 10 & 10 & 10 & 10 & 10 & 10 & 10 \\
\hline SPOM & - & - & 2 & 7 & 5 & 8 & 7 & 7 & 5 & 8 & 7 \\
\hline BPOM & - & - & - & 10 & 10 & 10 & 10 & 10 & 10 & 10 & 10 \\
\hline
\end{tabular}

SPOM = suspended particulate organic matter; BPOM = benthic particulate organic matter .

an July 2009, animal and plant epiphytes from litter fragments were not distinguished for fatty acid analysis.

replicates are detailed in Table 1 . All samples were ovendried at $60{ }^{\circ} \mathrm{C}$ for $72 \mathrm{~h}$. Amphipods were analysed whole, but all food items were ground into a homogeneous powder. As inorganic carbon present in samples can be a source of bias in $\mathrm{C}$ stable isotope ratio analysis, carbonates were removed by acidification. Tissues containing moderate amounts of carbonates (animal and plant epiphytes, SPOM, amphipods) were acidified using $\mathrm{HCl}$ vapors. Sediment sampled for BPOM analysis required direct addition of $\mathrm{HCl} 1 \mathrm{~N}$, due to its higher carbonate content. Tissues containing little or no carbonates (Posidonia oceanica leaves and litter) were not acidified.

Isotopic measurements were performed by continuous flow - elemental analysis - isotope-ratio mass spectrometry (CF-EA-IRMS) using an Optima mass spectrometer (Isoprime, Cheadle, UK), coupled to a NA1500 elemental analyser (Carlo Erba, Milan, Italy). Acidified samples were analysed in two runs: one for $\mathrm{C}$ isotope ratios, using decarbonated material, and one for $\mathrm{N}$ isotope ratios, using native material, as acidification is known to alter $\mathrm{N}$ stable isotope ratios. Isotopic ratios were expressed using the widespread $\delta$ relative notation (Coplen 2011). Sucrose (IAEA-C6, $\delta^{13} \mathrm{C}=-10.8 \pm 0.5 \%$ ) and ammonium sulfate (IAEA-N $1, \delta^{15} \mathrm{~N}=0.4 \pm 0.2 \%$ ) were used as certified reference materials for the measurement of isotopic ratios. Both of these certified materials are calibrated against the international isotopic references Vienna Pee Dee Belem- nite (for carbon) and Atmospheric Air (for nitrogen). Standard deviations on multi-batch replicate measurements of plant (P. oceanica leaf mix) and animal (amphipod pool) lab standards were $0.2 \%$ for $\delta^{13} \mathrm{C}$ and $0.3 \%$ for $\delta^{15} \mathrm{~N}$. All values are presented in the mean \pm SD form.

The Stable Isotope Analysis in R (SIAR) mixing model was used to numerically estimate the contributions of each food item to the diet of amphipods. This model, based on Bayesian methods, is capable of dealing with uncertainty and variability in input data, even in underdetermined systems (Parnell et al. 2010). Model runs were performed using only carbon data, as nitrogen did not improve isotopic discrimination between food items (cf. Results section) but limited the size of data sets (Table 1). To improve model performance, items that were pointed out as unlikely food sources by fatty acid analyses and/or gut content examination (SPOM, BPOM, living seagrass leaves, see Discussion section) were discarded. In addition, as their $\delta^{13} \mathrm{C}$ values were similar (cf. Results), animal and plant epiphytes of leaves and litter fragments were aggregated and considered as one group. Three sources were therefore used for the SIAR modeling: (i) P. oceanica litter, (ii) rhizome epiflora and (iii) leaves and litter epiphytes. The use of adequate trophic enrichment factors $\left(\Delta^{13} \mathrm{C}\right.$, i.e. the difference between the $\delta^{13} \mathrm{C}$ of consumer tissues and the $\delta^{13} \mathrm{C}$ of potential food items) is crucial to mixing model performance. Following the 
recommendations of Caut et al. (2008), a $\Delta^{13} \mathrm{C}$ value measured during a controlled experiment involving two of the studied amphipod taxa (Dexamine spiniventris and Gammarus spp.) fed with a mixture of live P. oceanica leaf epiphytes was used. This $\Delta^{13} \mathrm{C}$ value was $0.2 \pm 0.6 \%$ (mean \pm SD; Michel 2011). Model solutions were presented using credibility intervals of probability density function distributions (Parnell et al. 2010).

\section{Results}

\section{Gut contents}

The occurrence of empty guts was low, and ranged from $0 \%$ to $15 \%$ (three of the 20 analysed individuals) depending upon the considered species (Table 2). Most of the gut contents consisted of amorphous material lacking any identifiable structure. In most cases, it was not possible to link this with a given food item group. The abundance of this unidentifiable amorphous material ranged from $60 \%$ to $85 \%$ of the gut contents, depending on the species (Table 2). Among the identifiable fraction, fragments of macroalgae were the most commonly encountered food item. They were present in all but one examined individuals, and represented $15 \%$ to $35 \%$ of ingested material (Table 2). Most algal fragments were too damaged to be associated to a precise algal group. The few that could be mostly originated from erect macroalgae, usually Phaeophyceae (Myrionema sp., Sphacelariales) and Rhodophyceae (notably Ceramiales). All species, with the exception of Caprella acanthifera, seemed to consume other crustaceans. However, crustacean remains (mostly legs, but also mandibles and antennas) were infrequent (two to five individuals of each species) and their mean contributions were typically low (1.5\% to $4.5 \%)$. In most cases, crustacean parts seemed to originate from other amphipods, or at least from other peracarids. Dead Posidonia oceanica leaf fragments (litter) were found in three of the seven species. While they were rare in Dexamine spiniventris and Gammarella fucicola, they were found in the majority (13 out of 18) of Gammarus aequicauda specimens, where they constituted nearly $4 \%$ of the gut content. No living fragments of seagrass leaves were found in any of the examined individuals. Finally, diatoms and pieces of sessile invertebrates (fragments of hydrozoan perisarc, bryozoan zoids, foraminiferans) were identified, but accounted for very low mean contributions in all cases (typically $<0.5 \%$ ).

\section{Fatty acids}

The fatty acid (FA) composition of all epiphytic groups (i.e. leaf epifauna and epiflora, bulk litter epiphytes and rhizome epiflora) exhibited comparable major fatty acids (Table 3). Saturated fatty acids (SAFAs) and polyunsaturated fatty acids (PUFAs) both accounted for around $40 \%$ of the total FAs in all groups except leaf epifauna, which contained more SAFAs than PUFAs $(46.0 \%$ and $31.0 \%$, respectively). The major SAFA of epiphytes was 16:0 (generally about $30 \%$ of total). The dominant PUFAs were 20:5(n-3), 20:4(n-6) and, to a lesser extent, 18:2 (n-6) and 18:3(n-3). Monounsaturated fatty acids (MUFAs) were less abundant, with relative proportions around 20\%. The most common MUFAs were 16:1(n-7), 18:1(n-9) and 18:1(n-7).

Compared with the other food items, the distribution of FAs in living P. oceanica leaves was strikingly different. It was dominated by PUFAs (67.7\%, Table 3), with high amounts of $\alpha$-linolenic acid [18:3(n-3), 37.9\%] and linoleic acid [18:2(n-6), 25.2\%]. By contrast, icosapentanoic acid [20:5(n-3)] and arachidonic acid [20:4(n-6)] were scarce $(<0.5 \%)$. The proportion of SAFAs $(28.4 \%)$, and MUFAs $(<4 \%)$ was considerably lower compared with other sources. The major FAs of $P$. oceanica litter were SAFAs (over $50 \%$, Table 3), dominated by 16:0, accounting for 22.4\%. The amount of PUFAs was much lower

Table 2. Composition of amphipod gut contents.

\begin{tabular}{|c|c|c|c|c|c|c|c|c|c|c|c|c|c|}
\hline \multirow[b]{2}{*}{ Species } & \multirow[b]{2}{*}{$\mathrm{N}$} & \multicolumn{2}{|l|}{ Alg } & \multicolumn{2}{|c|}{ Crust } & \multicolumn{2}{|c|}{ POLit } & \multicolumn{2}{|c|}{ Diat } & \multicolumn{2}{|c|}{ SInv } & \multicolumn{2}{|c|}{ Unid } \\
\hline & & Oc & $\%$ & Oc & $\%$ & Oc & $\%$ & Oc & $\%$ & Oc & $\%$ & Oc & $\%$ \\
\hline Apherusa chiereghinii & 20 & 20 & 19.7 & 2 & 2.2 & 0 & - & 12 & 0.6 & 9 & 0.1 & 20 & 77.4 \\
\hline Aora spinicornis & 18 & 18 & 20.1 & 3 & 2.1 & 0 & - & 11 & 0.2 & 11 & 0.4 & 18 & 77.3 \\
\hline Dexamine spiniventris & 17 & 17 & 35.2 & 2 & 2.4 & 2 & 2.9 & 13 & 0.3 & 2 & 0.1 & 17 & 59.2 \\
\hline Ampithoe helleri & 17 & 16 & 22.7 & 2 & 1.8 & 0 & - & 6 & 0.1 & 6 & 0.2 & 17 & 75.1 \\
\hline Caprella acanthifera & 18 & 18 & 14.3 & 0 & - & 0 & - & 2 & 0.1 & 11 & 0.5 & 18 & 85.1 \\
\hline Gammarella fucicola & 19 & 19 & 36.4 & 3 & 1.6 & 6 & 1.9 & 10 & 0.4 & 10 & 0.3 & 19 & 59.4 \\
\hline Gammarus aequicauda & 18 & 18 & 23.9 & 5 & 4.3 & 13 & 3.9 & 16 & 0.3 & 0 & - & 18 & 67.6 \\
\hline
\end{tabular}

$\mathrm{N}=$ number of individuals whose gut contained material; Oc = occurrence of a given food item in the gut contents of a species; $\%=$ mean relative abundance of a given food item expressed as a percentage of the total gut content area. Alg. = macroalgae; Crust = crustacean remains; POLit = Posidonia oceanica litter; Diat = diatoms; SInv = sessile invertebrates; Unid = unidentifiable amorphous material. 
Table 3. Mean fatty acid composition (mass \%) of total lipids of food sources and amphipods.

\begin{tabular}{|c|c|c|c|c|c|c|c|c|c|c|c|c|c|c|}
\hline Fatty acid & POLV & POLit & SPOM & RhEfl & LitEpi & LvEfl & LvEfn & $A c$ & As & Ds & Ah & $\mathrm{Ca}$ & Gf & $\mathrm{Ga}$ \\
\hline$\Sigma$ SAFA & 28.35 & 50.62 & 50.22 & 39.46 & 41.69 & 41.60 & 46.01 & 29.57 & 34.57 & 32.34 & 43.87 & 40.15 & 34.26 & 24.88 \\
\hline $16: 0$ & 19.20 & 22.38 & 28.12 & 29.35 & 28.53 & 29.79 & 29.35 & 23.94 & 22.40 & 20.19 & 29.45 & 25.98 & 21.86 & 17.43 \\
\hline $18: 0$ & 5.70 & 9.46 & 10.41 & 3.72 & 4.13 & 5.25 & 8.46 & 4.42 & 9.60 & 8.48 & 7.01 & 10.69 & 8.53 & 4.79 \\
\hline Other SAFA & 3.45 & 18.78 & 11.69 & 6.39 & 9.03 & 6.56 & 8.20 & 1.21 & 2.58 & 3.67 & 7.41 & 3.49 & 3.86 & 2.65 \\
\hline$\Sigma$ MUFA & 3.90 & 23.21 & 22.31 & 18.66 & 21.74 & 17.88 & 22.99 & 23.70 & 21.70 & 22.00 & 26.97 & 26.39 & 21.16 & 31.59 \\
\hline $16: 1(n-7)$ & 0.37 & 4.22 & 9.42 & 4.24 & 6.40 & 5.59 & 8.94 & 4.12 & 3.94 & 1.85 & 2.92 & 2.77 & n.d. & 3.36 \\
\hline $18: 1(n-7)$ & 0.38 & 7.11 & 1.78 & 6.96 & 4.52 & 2.79 & 3.11 & 4.03 & 3.50 & 2.21 & 2.48 & 3.48 & 3.33 & 10.68 \\
\hline 18:1(n-9) & 2.55 & 8.09 & 7.59 & 5.02 & 7.40 & 8.28 & 7.60 & 14.21 & 12.52 & 15.13 & 18.83 & 14.49 & 14.96 & 14.64 \\
\hline Other MUFA & 0.60 & 3.79 & 3.52 & 2.44 & 3.42 & 1.23 & 3.33 & 1.34 & 1.73 & 2.81 & 2.73 & 5.65 & 2.87 & 2.92 \\
\hline$\Sigma$ PUFA & 67.74 & 26.17 & 27.47 & 41.88 & 36.57 & 40.51 & 31.01 & 46.74 & 43.73 & 45.66 & 29.16 & 33.45 & 44.59 & 43.54 \\
\hline $18: 2(n-6)$ & 25.17 & 3.87 & 5.08 & 7.03 & 3.13 & 7.67 & 2.85 & 3.46 & 2.41 & 4.12 & 2.71 & 1.80 & 2.81 & 3.30 \\
\hline $18: 3(n-3)$ & 37.93 & 3.37 & 1.24 & 1.80 & 2.73 & 5.69 & 3.65 & 1.84 & 0.42 & 2.41 & 0.48 & n.d. & 0.95 & 1.56 \\
\hline $20: 4(n-6)$ & 0.30 & 2.12 & 2.73 & 14.62 & 8.34 & 10.91 & 8.60 & 11.54 & 14.37 & 15.78 & 4.55 & 8.95 & 9.18 & 15.03 \\
\hline $20: 5(n-3)$ & 0.21 & 4.50 & 5.61 & 10.53 & 11.90 & 9.55 & 6.27 & 20.14 & 16.52 & 16.16 & 9.78 & 9.45 & 17.70 & 13.86 \\
\hline $22: 6(n-3)$ & 0.05 & 1.42 & 3.90 & 1.78 & 1.26 & 1.20 & 2.83 & 6.17 & 6.22 & 3.12 & 7.86 & 10.87 & 7.43 & 6.86 \\
\hline Other PUFA & 4.08 & 10.89 & 8.92 & 6.12 & 9.20 & 5.50 & 6.82 & 3.57 & 3.79 & 4.07 & 3.79 & 2.38 & 6.52 & 2.93 \\
\hline$\frac{16: 1(\mathrm{n}-7)}{16: 0}$ & & & & & & & & 0.17 & 0.18 & 0.09 & 0.10 & 0.11 & 0.00 & 0.20 \\
\hline$\Sigma C_{18}+C_{20}$ PUFA & & & & & & & & 39.24 & 35.78 & 41.59 & 21.31 & 20.94 & 37.16 & 35.14 \\
\hline$\frac{18: 2(\mathrm{n}-6)+18: 3(\mathrm{n}-3)}{\sum C_{20}+C_{22} \text { PUFA }}$ & & & & & & & & 0.14 & 0.07 & 0.18 & 0.09 & 0.13 & 0.13 & 0.06 \\
\hline
\end{tabular}

SAFA = saturated fatty acids; MUFA = monounsaturated fatty acids; PUFA = polyunsaturated fatty acids = and selected fatty acid markers; POLv = Posidonia leaves; $\quad$ POLit $=$ Posidonia litter; $\mathrm{SPOM}=$ suspended particulate organic matter; RhEfl $=$ rhizome epiflora; LitEpi $=$ litter epiphytes; LvEfl = leaves epiflora; LvEfn= leaves epifauna; Ac = Apherusa chiereghinii; As = Aora spinicornis; Ds = Dexamine spiniventris; $\mathrm{Ah}=$ Ampithoe helleri; $\mathrm{Ca}=$ Caprella acanthifera; $\mathrm{Gf}=$ Gammarella fucicola; Ga = Gammarus aequicauda; $\mathrm{n} . \mathrm{d}$. $=$ not detected.

than in living leaves, summing up to $26.2 \%$, with the proportions of 18:2(n-6) and 18:3(n-3) each contributing to $<4 \%$ of the total FAs. MUFAs were more abundant than in the leaves, and the dominant compounds were the same as in epiphytic tissues. The FA composition of SPOM was in some ways comparable to that of P. oceanica litter, with high proportions of SAFAs. However, $18: 1(n-7)$ only accounted for $1.8 \%$ in SPOM, compared with $7.1 \%$ in $P$. oceanica litter.

SAFAs accounted for $30-35 \%$ in four of the seven species of amphipods (Apherusa chiereghinii, Aora spinicornis, Dexamine spiniventris and Gammarella fucicola, Table 3). They were rarer in Gammarus aequicauda (24.9\%), but more abundant in Ampithoe helleri and Caprella acanthifera $(43.9 \%$ and $40.2 \%$, making them the predominant class in these two species). In all cases, 16:0 was the most abundant SAFA, always followed by 18:0. MUFAs were relatively rare in four of the seven species (Ap. chiereghinii, Ao. spinicornis, D. spiniventris and Gammarella fucicola), accounting for little more than $20 \%$. They were more abundant in Gammarus aequicauda (31.6\%), and, to a lesser extent, in Am. helleri (27.0\%) and C. acanthifera (26.4\%). 18:1(n-9) was always the most common MUFA, accounting for $12.5 \%$ (in Ao. spinicornis) to $18.8 \%$ (in Am. helleri). 18:1(n-7) was also present in moderate amounts $(2.2 \%$ to $4.0 \%)$, with the exception of in
Gammarus aequicauda, where it reached more than $10 \%$. $16: 1(n-7)$ concentrations ranged from $1.9 \%$ to $4.1 \%$ in six of the seven species, but this compound was totally absent from Gammarella fucicola. PUFAs accounted for about $45 \%$ of the total lipid content of five of the studied species (Ap. chiereghinii, Ao. spinicornis, D. spiniventris, Gammarella fucicola and Gammarus aequicauda), making them the most abundant FA class in these species. In these five species, most of the PUFA pool was made up of 20:5(n-3) and 20:4(n-6). PUFAs were not that abundant in tissues of Am. helleri (29.2\%) and C. acanthifera $(33.5 \%)$. Moreover, in these two species, 20:4(n-6) and 20:5(n-3) were scarcer, and their contributions were comparable with those of 22:6(n-3). This latter FA was particularly abundant in C. acanthifera, accounting for more than $10 \%$ of the total lipid content.

2D ordination of amphipod FA data through non-metric MDS (Fig. 1) showed that they were scattered over three groups. Intra-group similarity was over $80 \%$ in each case. Group A was the only monospecific one, and contained four of the eight Gammarus aequicauda samples. Group B contained nine D. spiniventris samples out of 11, as well as one Gammarus aequicauda, the only Am. helleri and Gammarella fucicola pools, and two of the five Ao. spinicornis samples. Group C contained all Ap. chiereghinii samples, alongside the two remaining 
Fig. 1. 2D ordination of all amphipod samples, obtained via non-metric multidimensional scaling, using Bray-Curtis similarities computed on $\sqrt{ }$-transformed fatty acid compositions (mass \%) of total lipids. Dashed and solid lines represent $75 \%$ and $80 \%$ similarity, respectively.

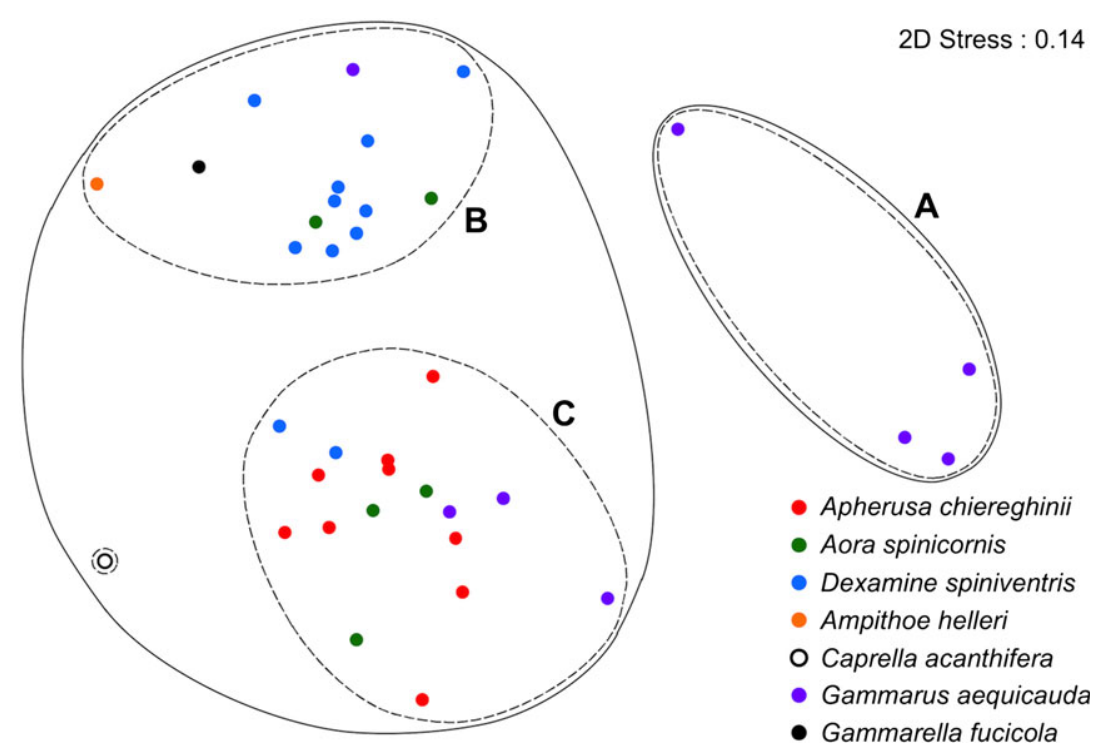

D. spiniventris, three Ao. spinicornis and three Gammarus aequicauda. Finally, the only C. acanthifera was found outside all groups. Overall similarity between samples was high (more than 70\%), and an a posteriori one-way SIMPER analysis showed the only useful variable to explain inter-group differences was the proportion of the 18:1(n7) FA, which was much higher in the four Gammarus aequicauda of group A (16.2\%) than in amphipods of groups B $(2.6 \%)$ or C $(3.8 \%)$.

\section{Stable isotope ratios}

Isotopic ratios of amphipods and food items exhibited little to no seasonal variation, motivating our choice to plot all values together on a single graph (Fig. 2). $\delta^{13} \mathrm{C}$ values allowed separation of the food sources into three major groups. Posidonia oceanica leaves and litter showed similar values and were by far the less negative sources $\left(\delta^{13} \mathrm{C}=-13.2 \pm 0.7 \%\right.$ and $-13.2 \pm 0.9 \%$, respectively $)$. At the other end of the range, SPOM $\left(\delta^{13} \mathrm{C}=\right.$ $-26.3 \pm 1.1 \%$ and rhizome epiflora $\left(\delta^{13} \mathrm{C}=-28.4 \pm\right.$ $1.0 \%$ o ) were the most ${ }^{13} \mathrm{C}$-depleted food items. Between these two groups, BPOM and animal and plant epiphytes from leaves and litter fragments formed an overlapping cluster ('median' sources), approximately ranging from $-17 \%$ to $-21 \%$. All food items were found in the same $\delta^{15} \mathrm{~N}$ interval, as most values ranged from $1 \%$ to $3 \%$. Inside this interval, the signatures of food sources broadly overlapped, and no clear differences could be made out between them.

Dexamine spiniventris showed the most negative carbon signature of all the amphipod species $\left(\delta^{13} \mathrm{C}=-26.6 \pm\right.$ $1.1 \%$, Fig. 2). This $\delta^{13} \mathrm{C}$ value was comparable with the one of the most negative food sources (SPOM and rhi- zome epiflora). By contrast, Gammarus aequicauda was the least ${ }^{13} \mathrm{C}$-depleted of all amphipod species $\left(\delta^{13} \mathrm{C}=-15.6 \pm 1.1 \%\right.$ oo. It occupied an intermediate position between the 'median' (BPOM and epiphytes from leaves and litter) and the $P$. oceanica-derived food sources. The $\delta^{13} \mathrm{C}$ of Apherusa chiereghinii (-18.6 \pm $0.9 \%$ ) and Aora spinicornis $(-19.7 \pm 0.8 \%$ ) coincided with the range of $\delta^{13} \mathrm{C}$ of the median food sources. Gammarella fucicola was found between the most negative and the median food sources, with a $\delta^{13} \mathrm{C}$ of $-22.6 \pm 1.0 \%$. Finally, $\quad \delta^{13} \mathrm{C}$ values of Caprella acanthifera $(-20.7 \pm 0.7 \%$ o $)$ and Ampithoe helleri $(-20.9 \pm 0.8 \%$ o typically fell between those of Gammarella fucicola and those of the median food sources, and partially overlapped the values of the latter. $\delta^{15} \mathrm{~N}$ of all amphipods widely overlapped in a $1.5 \%$ to $4.0 \%$ range. In a lot of cases, amphipod signatures covered those of the food sources. Trophic enrichment factors $\left(\Delta^{15} \mathrm{~N}\right.$, i.e. the difference between the $\delta^{15} \mathrm{~N}$ of consumer tissues and the $\delta^{15} \mathrm{~N}$ of potential food items) were always low (from $0 \%$ to $1.8 \%$, according to the considered species/food source pair).

The SIAR mixing model (Fig. 3) indicated that the proportion of $P$. oceanica litter in the diet of Gammarus aequicauda was considerable, as the $75 \%$ credibility interval $\left(\mathrm{CI}_{75}\right)$ ranged from $27 \%$ to $35 \%$. This situation is unique among the studied amphipods, as contribution of this source to the diet of other species was low or negligible. Besides this, SIAR outputs suggested that contribution of rhizome epiflora and of leaf and litter epiphytes to the diet of Gammarus aequicauda were fairly similar. Model estimates pointed out that D. spiniventris forages almost exclusively on rhizome epiphytes $\left[\mathrm{CI}_{75}=(99 \%\right.$, $100 \%)]$. The diet of the five remaining species appeared 


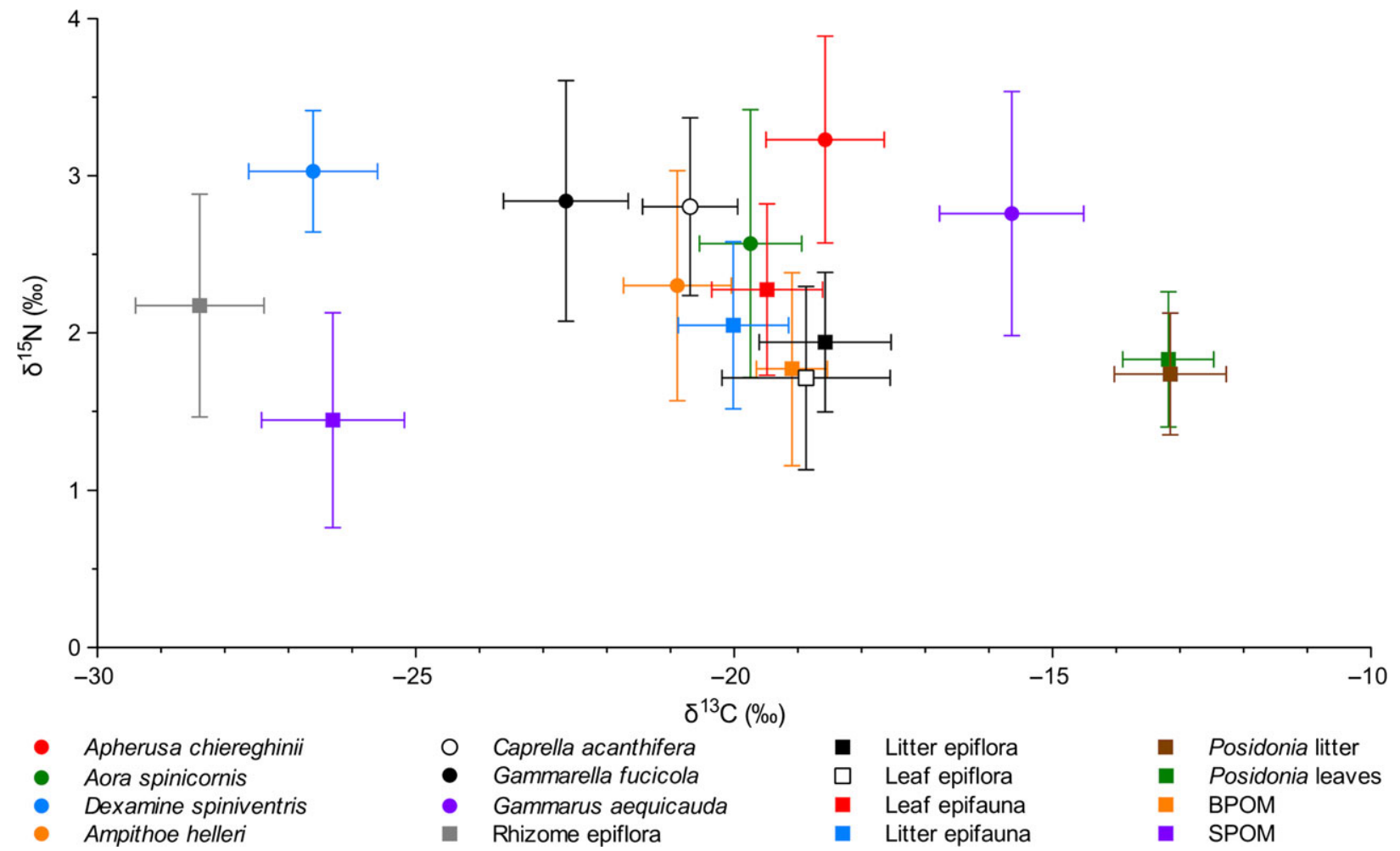

Fig. 2. Mean values $( \pm \mathrm{SD})$ of $\delta^{13} \mathrm{C}(\%)$ and $\delta^{15} \mathrm{~N}(\%)$ of amphipods (circles) and potential food items (squares).

to be mostly made up of rhizome, leaves and litter epiphytes, in variable proportions (Fig. 3). In the case of Ap. chiereghinii, leaf and litter epiphytes were more abundant than those growing on rhizomes $\left[\mathrm{CI}_{75}=(27 \%\right.$, $77 \%)$ and (18\%, 59\%), respectively]. By contrast, rhizome epiflora was the major contributor to the diets of Gammarella fucicola $\left[\mathrm{CI}_{75}=(58 \%, 74 \%)\right]$, C. acanthifera $\left[\mathrm{CI}_{75}=(51 \%, 62 \%)\right]$ and Am. helleri $\left[\mathrm{CI}_{75}=(46 \%\right.$, $65 \%)]$. Finally, proportions of the two groups of items were comparable in the case of Ao. spinicornis $\left[\mathrm{CI}_{75}=\right.$ $(33 \%, 55 \%)$ for leaf and litter epiphytes and (39\%, 58\%) for rhizome epiflora].

\section{Discussion}

The dominant trophic fluxes in Posidonia oceanica meadows involve interactions between consumers and multiple primary producers as well as other organic matter sources, notably detrital items. As a result, food-web dynamics are complex and knowledge of their implications for ecosystem functioning is still inadequate (Vizzini 2009). In this study, we focused on the importance of several readily available food items for amphipod nutrition.

Although deposit feeding is a widespread foraging mode among amphipods from numerous ecosystems, examination of gut contents suggested that it was not a major trophic activity in the studied species. Indeed, no gut from any of the examined amphipods contained inorganic sediment particles. Deposit feeding generally implies ingestion of such particles that are often abundant, or at least present, in the gut contents of deposit feeders (e.g. Graeve et al. 2001). Their total absence suggests that BPOM is not an important food source for any of the considered consumers.

Fatty acid markers pointed out that none of the studied amphipods consume living Neptune grass tissues. 18:2(n-6) and 18:3(n-3) FAs are extremely abundant in most Chlorobionta, including seagrasses, but are rather rare in Phaeophyta and Rhodophyta (Kayama et al. 1989; Graeve et al. 2002). Proportions of these two FAs were accordingly high (over $60 \%$ of the total FAs, Table 3 ) in living P. oceanica leaves. $\mathrm{C}_{20}$ and $\mathrm{C}_{22}$ PUFAs, however, are abundant in all marine plants, either macro- and micro-algae or seagrasses (Kayama et al. 1989). The ratio between $\mathrm{C}_{18}$ and $\mathrm{C}_{20-22}$ PUFAs has therefore been proposed as a marker for seagrass consumption (Kharlamenko et al. 2001). This ratio was very low for all studied species here (Table 3), indicating a lack of seagrass grazing. Gut content examination also suggested that consumption of living Neptune grass tissues does 


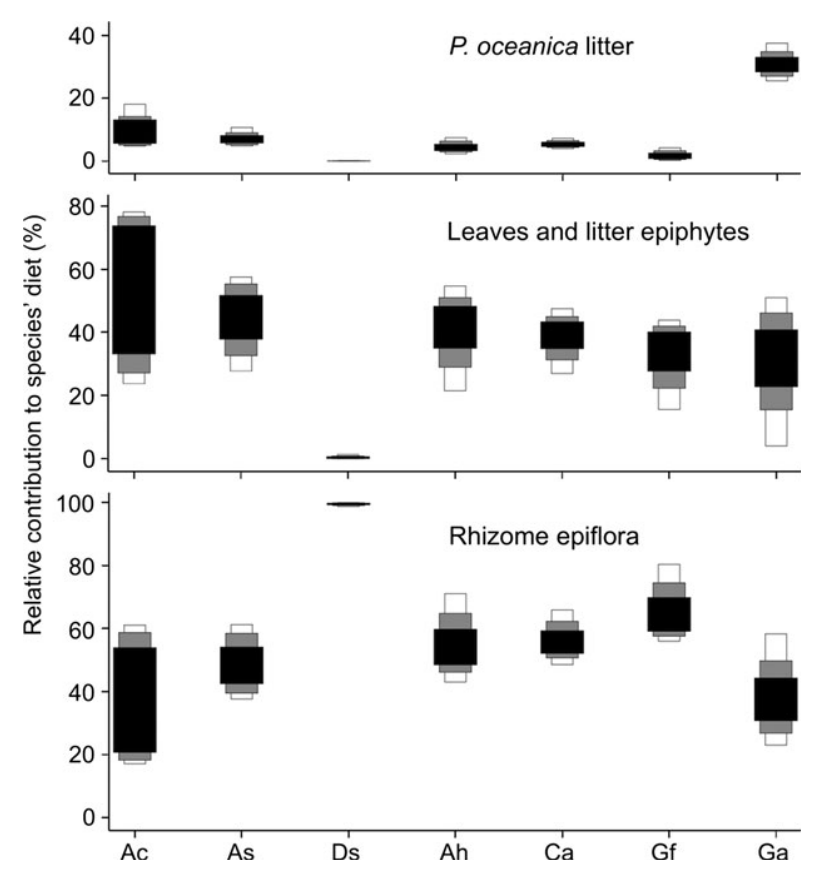

Fig. 3. Boxplots of relative contributions of most likely food items to the diet of amphipods, computed using the Stable Isotope Analysis in $\mathrm{R}$ model. Black, grey and white boxes are the 50\%, 75\% and 95\% credibility intervals, respectively. Ac, Apherusa chiereghinii; As, Aora spinicornis; Ds, Dexamine spiniventris; Ah, Ampithoe helleri; Ca, Caprella acanthifera; Gf, Gammarella fucicola; Ga, Gammarus aequicauda.

not occur, as these were totally absent in all species. This supports the view that most primary consumers from $P$. oceanica meadows do not feed on their seagrass host (Dauby 1989; Lepoint et al. 2000; Vizzini et al. 2002). Although herbivory can have a substantial impact on leaf biomass (Prado et al. 2007), Neptune grass seems to be grazed by only a few consumers. These include the fish Sarpa salpa, the urchin Paracentrotus lividus and isopods from the genus Idotea (Mazzella et al. 1992). This is probably explained by the low palatability (hard tissues containing a lot of structural carbohydrates) and nutritional quality (high $\mathrm{C} / \mathrm{N}$ ratios) of seagrass leaves. Moreover, living $P$. oceanica leaves contain high amounts of phenolic compounds that could act as herbivore repellents (Gobert et al. 2006; Vizzini 2009). The situation is quite different in other temperate seagrass meadows. In Californian Zostera marina meadows, diet of mixed Caprellidae and Ampithoidae are composed of about 50\% and $60 \%$ of seagrass material, respectively (Farlin et al. 2010). One key difference could be the abundance of epiphytic organisms, typically greater in $P$. oceanica meadows than in other seagrass systems (Mazzella et al. 1989). As epiphytes are more easily digestible and have better nutritional quality, amphipods may preferentially graze on them, and only consume their seagrass host when availability of other items is low (Valentine \& Duffy 2006).

Although none of the studied amphipods grazed on its seagrass host while it was alive, three species ingested fragments of $P$. oceanica litter (Table 2). Dexamine spiniventris and Gammarella fucicola had very negative $\delta^{13} \mathrm{C}$ values, and mixing model analysis indicated that the contribution of $P$. oceanica-derived organic matter to the diet of these species was low to nil $(<0.1 \%$ and $0.2 \%$ to $4.2 \%$, respectively). For these species, litter fragments may have been accidentally ingested while feeding on other benthic items from the lower horizons of the meadow. Gammarus aequicauda, by contrast, had a $\delta^{13} \mathrm{C}$ value compatible with actual assimilation of seagrass detritus. SIAR analysis suggested that about a third of its diet $\left[\mathrm{CI}_{95}=(26 \%\right.$, $38 \%)$ ] was composed of P. oceanica litter, alongside important amounts of macroalgae. These proportions are comparable with, yet lower, than those obtained for Gammarus aequicauda specimens sampled in submerged phytodetritus accumulations (Lepoint et al. 2006). The fact that consumption and assimilation of $P$. oceanica detritus occurs in different habitats suggests a specialization of Gammarus aequicauda to efficiently exploit this poorly digestible material. Mutualistic associations with bacterial symbionts probably enhance the litter degradation capabilities of this species (G. Lepoint, unpublished observations). By consuming dead seagrass material directly inside the meadow, i.e. as soon as it starts to accumulate, it likely participates in the fragmentation and recycling of this abundant material. It could therefore play a significant role in the detrital pathway, which is the fate of most P. oceanica production (Pergent et al. 1997).

Diatoms are one of the dominant groups of phytoplankton in Calvi Bay (Dauby 1989), as well as the most common item among microepiphytes from P. oceanica leaves and litter (Buia et al. 2000). Here, FA analyses suggested that the diatom contribution to amphipod diet is low. 16:1(n-7) FA is indeed an important component of diatoms, in which it generally outnumbers the otherwise dominant 16:0 (Cook et al. 2010). The ratio of 16:1(n-7) to $16: 0$ concentrations can therefore be used as a marker for a diatom-based diet (Kharlamenko et al. 2001). In tissues of consumers relying heavily on either pelagic or benthic diatoms, this ratio is typically close to or $>1$ (Kharlamenko et al. 1995; Graeve et al. 1997, 2001). In this study, these ratios were much lower (always $<0.2$; Table 3). In addition, diatoms frustules were scarce (always $<1 \%$ ) or even absent from gut contents of amphipods (Table 2). Reliance of amphipods on suspended particulate organic matter and/or microepiphytes is therefore unlikely. This is striking, as microepiphytes are common food items for mesograzers from P. oceanica meadows, notably gastropod mollusks (Mazzella \& Russo 
1989; Buia et al. 2000). These different feeding habits clearly emphasize the high degree of trophic diversity present among different groups of herbivorous invertebrates inhabiting the $P$. oceanica meadow canopy. Epiphytic and/or epipelic diatoms also appear to be the main food source of some species of herbivorous amphipods from Z. marina meadows (Jaschinski et al. 2008; Jeong et al. 2012). In P. oceanica meadows, however, amphipods seem to graze preferentially on macroepiphytes, stressing once again how trophodynamic processes can differ among temperate seagrass meadows.

Epiphytic macroalgae seemed to be central items in the diet of all the organisms studied here. Total lipids of amphipods contained important amounts of (n-3) and (n-6) PUFAs, mostly represented by $\mathrm{C}_{18}$ and $\mathrm{C}_{20}$ compounds (Table 3). These compounds are abundant in all marine plants (Kayama et al. 1989), and their summed concentrations can therefore be used as a FA marker for herbivory (Kharlamenko et al. 1995). The abundance of $\mathrm{C}_{18}$ and $\mathrm{C}_{20}$ PUFAs in amphipod tissues (Table 3 ) suggests that herbivory is a major feeding type for all the studied organisms. As seagrass and diatom consumption are negligible, macroalgal epiphytes likely make up most of the plant-based material of the amphipod diet. Moreover, FA composition of amphipods was quite similar to that of the epiphytic food items (Table 3). Algal fragments were also the most frequently occurring identifiable item in the gut contents of all species (Table 2). Stable isotope ratios of carbon allowed classification of amphipods into four groups. The first one was composed of Apherusa chiereghinii and Aora spinicornis. $\delta^{13} \mathrm{C}$ values of these animals coincide with those of animal and plant epiphytes from leaves and litter, as well as with those of BPOM. As examination of gut contents suggested that deposit feeding is not a likely feeding type, these amphipods are probably grazers feeding mostly on epiphytes from $P$. oceanica leaves and litter fragments (Table 4). The second group only contained D. spiniventris. The very negative $\delta^{13} \mathrm{C}$ of this species suggests that it feeds on the most ${ }^{13} \mathrm{C}$-depleted items, i.e. rhizome epiflora and/or SPOM. As gut content examination and FA composition analysis indicated that suspension feeding is rare, this amphipod probably grazes on epiphytes growing on the lower parts of the plant (Table 4). Three species (Gammarella fucicola, Caprella acanthifera and Ampithoe helleri) had $\delta^{13} \mathrm{C}$ values that fell between those of one of the 'more negative' and 'median' food sources, indicating a mixed diet composed of both of these groups of food items. They may therefore be opportunistic grazers, feeding on epiphytes growing on all parts of the plant (Table 4). Finally, Gammarus aequicauda had the least negative $\delta^{13} \mathrm{C}$ value of all amphipods, owing to its partial reliance on $P$. oceanica detritus as a carbon source. As its $\delta^{13} \mathrm{C}$ range was comprised between $P$. oceanica-derived organic matter and epiphytes from leaves and litter fragments, the rest of its diet is likely composed of this latter source (Table 4).

Occasional carnivory or necrophagy is common in a lot of marine herbivore invertebrates, and is often thought to be a strategy to achieve adequate nutrition by compensating for nitrogen-poor and non-digestible material-rich diets (Cruz-Rivera \& Hay 2000). Here, crustacean remains (legs, antennae, mouthparts) were seldom found in gut contents from any species except C. acanthifera (Table 2). Most of them seemed to originate from other amphipods, or at least from other peracarids. They may originate from consumption of smaller amphipods or from cannibalism, as well as from consumption of shed exuviae, as these three behaviors are documented in a number of amphipod species (Hunte \& Myers 1984; Bellan-Santini 1999). However, most $\Delta^{15} \mathrm{~N}$ values between amphipods and feasible food

Table 4. Summary of key findings about the diet of each consumer.

\begin{tabular}{|c|c|c|c|c|}
\hline \multirow[b]{2}{*}{ Species } & \multicolumn{3}{|l|}{ Main food sources } & \multirow[b]{2}{*}{ Conclusion } \\
\hline & Gut contents & Fatty acids & Stable isotopes & \\
\hline Apherusa chiereghinii & Macroalgae & Macroalgae & Epiphytes (leaves/litter) and/or BPOM & Epiphyte grazer (leaves/litter) \\
\hline Aora spinicornis & Macroalgae & Macroalgae & Epiphytes (leaves/litter) and/or BPOM & Epiphyte grazer (leaves/litter) \\
\hline Gammarus aequicauda & $\begin{array}{l}\text { Macroalgae, Posidonia } \\
\text { oceanica litter }\end{array}$ & Macroalgae & $\begin{array}{l}\text { Epiphytes (leaves/litter) and/or BPOM, } \\
\text { Posidonia oceanica leaves and/or litter }\end{array}$ & $\begin{array}{l}\text { Epiphyte grazer (leaves/litter), } \\
\text { Detritus feeder ( } P \text {. oceanica litter) }\end{array}$ \\
\hline Dexamine spiniventris & $\begin{array}{l}\text { Macroalgae, Posidonia } \\
\text { oceanica litter }\end{array}$ & Macroalgae & Epiphytes (rhizomes) and/or SPOM & Epiphyte grazer (rhizomes) \\
\hline Ampithoe helleri & Macroalgae & Macroalgae & $\begin{array}{l}\text { Epiphytes (leaves/litter) and/or BPOM, } \\
\text { epiphytes (rhizomes) and/or SPOM }\end{array}$ & Epiphyte grazer (leaves/litter/rhizomes) \\
\hline Caprella acanthifera & Macroalgae & Macroalgae & $\begin{array}{l}\text { Epiphytes (leaves/litter) and/or BPOM, } \\
\text { epiphytes (rhizomes) and/or SPOM }\end{array}$ & Epiphyte grazer (leaves/litter/rhizomes) \\
\hline Gammarella fucicola & $\begin{array}{l}\text { Macroalgae, Posidonia } \\
\text { oceanica litter }\end{array}$ & Macroalgae & $\begin{array}{l}\text { Epiphytes (leaves/litter) and/or BPOM, } \\
\text { epiphytes (rhizomes) and/or SPOM }\end{array}$ & Epiphyte grazer (leaves/litter/rhizomes) \\
\hline
\end{tabular}

SPOM = suspended particulate organic matter; BPOM = benthic particulate organic matter. 
items (epiphytes and P. oceanica detritus) ranged from $+0.5 \%$ to $+1.5 \%$ o. Such low $\Delta^{15} \mathrm{~N}$ values clearly indicate that amphipods feed directly on the sampled food items, and are mostly primary consumers. Ingestion of crustacean tissues, although it occurs, is therefore apparently not a significant source of organic matter.

Amphipods, notably caprellids, have been described as heavily preying on sessile animals (Ruffo et al. 1993). In $P$. oceanica meadows, animal epiphytes (mostly bryozoans and hydrozoans) are an often abundant, nutritionally valuable food source, as they have $\mathrm{C} / \mathrm{N}$ ratios similar to those of amphipods. They are found in close association with epiflora and could therefore be consumed alongside it. However, neither the FA nor stable isotope ratio analyses were sufficient to discriminate between plant and animal epiphytes from leaves and litter fragments. The significance of epifauna in amphipod diets is therefore hard to estimate using these methods. Sessile animals fragments were nearly absent from the guts of the studied species, suggesting that they are not major food items. Caution must however be taken, as their tissues seem to be comparatively softer than those of macroalgae and crustaceans. They might have been destroyed by the mechanical digestion, making them impossible to identify. They could therefore have been mislabeled as unidentifiable organic matter, leading to underestimation of their actual contribution to the diet. Overall, the question of the importance of epifauna as food items for amphipods remains open.

Delineating mesograzer diets in seagrass meadows is a difficult task, notably because of the complexity of organic matter fluxes (i.e. high number of food items), as well as the important similarity between sources. Each of the methods used had advantages and drawbacks, and was critical for specific aspects. Gut content examination only provides a snapshot of the diets of consumers. Moreover, here, most (60\% to $80 \%)$ of consumer guts were filled with amorphous material. This material was presumably of biogenic origin, and likely consisted of degraded organic elements. However, it was impossible to link this with a functional group of food items because of the lack of identifiable structures. This is probably caused by the typical feeding mechanisms of amphipods, which implies that most mechanical digestion takes place before food ingestion (Bellan-Santini 1999). The gut contents nevertheless indicated that deposit and suspension feeding were not major feeding types. Stable isotope ratios were very useful in differentiating epiphytic organisms from the leaf and litter fragments from those growing on rhizomes. However, they were unable to separate these two food sources from BPOM and SPOM, respectively. FA analyses also had limitations, and notably required large amounts of biological material, making individual measurements impossible. However, they showed that micro-herbivory, suspension feeding and live seagrass grazing were unlikely to happen. More importantly, it is the combination of the three techniques that proved to be successful. Combining data obtained using different methods indeed allowed us to draw insights that would not have been clear otherwise.

Our results indicated a certain extent of overlapping in the diets of the dominant species. Gut contents of all species seemed to be quite similar, and FA composition of the total lipids of all amphipods showed relatively high overall similarity (more than $70 \%$, Fig. 1). All species relied for a significant part of their organic matter intake on macroalgae. These macro-algae were presumably epiphytes growing on $P$. oceanica leaves, rhizomes and litter fragments, although drift photophilous and sciaphilous algae found among the litter may also be consumed. Interspecific differences in the feeding habits were nevertheless visible, notably in the compartments on which each species preferentially grazed (Table 4). Some of the species apparently consumed more epiphytes from the leaves and/or the litter fragments (Ap. chiereghinii, Ao. spinicornis, Gammarus aequicauda), while D. spiniventris appeared to specialize in grazing of the sciaphilous epiflora from rhizomes. Ampithoe helleri, C. acanthifera and Gammarella fucicola seemed to readily feed on both groups, and may be opportunistic grazers consuming epiphytes growing on all parts of the plant. These 'positional' differences in the grazing habits of amphipods may ensure efficient partitioning of resources offered by the epiphytic cover, and reduce trophic niche overlap. They may therefore limit food competition among the taxocenosis, as well as between amphipods and other mesograzers such as mollusks and polychaetes. In addition, diet mixing may also reduce competition for food. SIAR (Fig. 3) revealed that D. spiniventris was the only amphipod to feed on a single item. Besides their speciesspecific preferences, all other taxa exhibited a mixed diet, and seemed to feed on both epiphytes from leaves and litter and epiphytes from rhizomes. Exploitation of these multiple food items may be linked with the diel vertical migration behaviors displayed by amphipods (SánchezJerez et al. 1999; Michel 2011). Most species seem to spend the night in the foliar stratum, where they can graze on leaf epiphytes, but live in the lower layers of the meadow during daytime, and may therefore eat epiphytes from litter fragments and rhizomes at this time. Finally, alternative feeding modes also exist among the community, notably detritus feeding for Gammarus aequicauda.

Posidonia oceanica is one of the longest-lived seagrasses in the world. As a result, epiphytic communities growing on its leaves and rhizomes show a unique development. It is one of the most diverse and wellstructured communities found among all seagrasses, and 
can represent up to $40 \%$ of the foliar biomass (Mazzella et al. 1989). These epiphytes form an essential compartment of the meadow, and are of paramount importance in numerous processes (Buia et al. 2000). Here, we have shown that epiphytes growing on all parts of the plant were central items in the diet of dominant species of the abundant community of seagrass-associated amphipods. By consuming epiphytes, amphipods make the organic matter constituting them available to upper level consumers, and therefore hold a central role in the food webs associated with Neptune grass meadows. However, this importance in trophic interactions may not be their only ecological role. Their feeding activity may also influence the development of the epiphytic cover, and as dominant species have contrasting diets, the outcomes of their trophic interactions may also be different. Overall, amphipods definitely have the potential to impact the functioning of $P$. oceanica meadows, and may therefore be key features of these complex, pivotal, yet critically endangered ecosystems.

\section{Acknowledgements}

L. Michel and G. Lepoint were respectively supported by a research fellow and a research associate grant from Belgian Funds for Scientific Research (F.R.S.-FNRS). N. Thelen was a Belgian Fund for Research in Industry and Agriculture (FRIA) research fellow. The authors would like to thank Renzo Biondo (Laboratory of Oceanology, ULg) for his technical assistance in the conception and building of sampling gear, the staff of the STARESO Research station for their help during the fieldwork, as well as Celia Joaquim-Justo (Laboratory of Animal Ecology and Ecotoxicology, ULg) for granting access to the microscope used for gut content analyses. The authors are also indebted to Julien Jacquemart (Laboratory of Algology, Mycology and Experimental Systematics, ULg) for his help regarding identification of algal fragments in the gut contents. This paper is MARE publication no. 268.

\section{References}

Bay D. (1984) A field study of the growth dynamics and productivity of Posidonia oceanica (L.) Delile in Calvi Bay, Corsica. Aquatic Botany, 20, 43-64.

Bellan-Santini D. (1999) Ordre des Amphipodes (Amphipoda Latreille, 1816). In: Forest J. (Ed.), Traité de Zoologie Anatomie, Systématique, Biologie (Pierre-P. Grassé). Tome VII, Fascicule III A: Crustacés Péracarides. Institut Océanographique de Monaco, Monaco: 93-176.

Buia M.C., Gambi M.C., Zupo V. (2000) Structure and functioning of Mediterranean seagrass ecosystems: an overview. Biologia Marina Mediterranea, 7, 167-190.
Caut S., Angulo H., Courchamp F. (2008) Caution on isotopic model use for analyses of consumer diet. Canadian Journal of Zoology, 86, 438-445.

Chimenz C., Taramelli E., Cironi R., Contessini A., Gravina F., Maggiore F.R., Maj R.L.C., Motta M.G., Somaschini A. (1989) Studies on animal populations of leaves and rhizomes of Posidonia oceanica (L.) Delile on the rocky bottom of Torvaldaliga. In: Boudouresque C.F., Meinesz A., Fresi E., Gravez V. (Eds), International Workshop on Posidonia Beds. GIS Posidonie, Marseilles, France: 145-155.

Cook E.J., Shucksmith R., Orr H., Ashton G.V., Berge J. (2010) Fatty acid composition as a dietary indicator of the invasive caprellid, Caprella mutica (Crustacea: Amphipoda). Marine Biology, 157, 19-27.

Coplen T.B. (2011) Guidelines and recommended terms for expression of stable-isotope-ratio and gas-ratio measurement results. Rapid Communications in Mass Spectrometry, 25, 2538-2560.

Cruz-Rivera E., Hay M.E. (2000) The effects of diet mixing on consumer fitness: macroalgae, epiphytes, and animal matter as food for marine amphipods. Oecologia, 123, 252-264.

Dauby P. (1989) The stable carbon isotope ratios in benthic food webs of the Gulf of Calvi, Corsica. Continental Shelf Research, 2, 181-195.

Farlin J., Lewis L., Anderson T., Lai C. (2010) Functional diversity in amphipods revealed by stable isotopes in an eelgrass ecosystem. Marine Ecology Progress Series, 420, 277-281.

Gambi M.C., Lorenti M., Russo G.F., Scipione M.B., Zupo V. (1992) Depth and seasonal distribution of some groups of the vagile fauna of the Posidonia oceanica leaf stratum: structural and trophic analyses. Marine Ecology, 13, 17-39.

Gobert S., Cambridge M.L., Velimirov B., Pergent G., Lepoint G., Bouquegneau J.M., Dauby P., Pergent-Martini C., Walker D.I. (2006) Biology of Posidonia. In: Larkum A.W.D., Orth R.J., Duarte C.M. (Eds), Seagrasses: Biology, Ecology and Conservation. Springer, Berlin, Germany: 387408.

Graeve M., Kattner G., Piepenburg D. (1997) Lipids in Arctic benthos: does the fatty acid and alcohol composition reflect feeding and trophic interactions? Polar Biology, 18, 53-61.

Graeve M., Dauby P., Scailteur Y. (2001) Combined lipid, fatty acid and digestive tract content analyses: a penetrating approach to estimate feeding modes of Antarctic amphipods. Polar Biology, 24, 853-862.

Graeve M., Kattner G., Wiencke C., Karsten U. (2002) Fatty acid composition of Arctic and Antarctic macroalgae: indicator of phylogenetic and trophic relationships. Marine Ecology Progress Series, 231, 67-74.

Guerra-Garcia J.M., Tierna de Figueroa J.M. (2009) What do caprellids (Crustacea: Amphipoda) feed on? Marine Biology, 156, 1881-1890.

Hunte W., Myers R.A. (1984) Phototaxis and cannibalism in gammaridean amphipods. Marine Biology, 81, 75-79. 
Jaschinski S., Brepohl D.C., Sommer U. (2008) Carbon sources and trophic structure in an eelgrass Zostera marina bed, based on stable isotope and fatty acid analyses. Marine Ecology Progress Series, 358, 103-114.

Jeong S.J., Suh H.L., Kang C.K. (2012) Trophic diversity in amphipods within a temperate eelgrass ecosystem as determined by gut contents and $\mathrm{C}$ and $\mathrm{N}$ isotope analysis. Marine Biology, 159, 1943-1954.

Jernakoff P., Brearley A., Nielsen J. (1996) Factors affecting grazer-epiphytes interactions in temperate seagrass meadows. Oceanography and Marine Biology: an Annual Review, 34, 109 J. 162.

Kayama M., Araki S., Sato S. (1989) Lipids of marine plants. In: Ackman R.G. (Ed.), Marine Biogenic Lipids, Fats and Oils - Vol. II. CRC Press, Boca Raton: 3-48.

Kharlamenko V.I., Zhukova N.V., Khotimchenko S.V., Svetashev V.I., Kamenev G.M. (1995) Fatty acids as markers of food sources in a shallow-water hydrothermal ecosystem (Kraternaya Bight, Yankich Island, Kurile Islands). Marine Ecology Progress Series, 120, 231-241.

Kharlamenko V.I., Kiyashko S.I., Imbs A.B., Vyshkvartzev D.I. (2001) Identification of food sources of invertebrates from the seagrass Zostera marina community using carbon and sulfur stable isotope ratio and fatty acid analyses. Marine Ecology Progress Series, 220, 103-117.

Kikuchi T. (1980) Faunal relationships in temperate seagrass beds. In: Phillips R.C., McRoy C.P. (Eds), Handbook of Seagrass Biology - An Ecosystem Perspective. Garland, New York, NY: 153-172.

Lebreton B., Richard P., Galois R., Radenac G., Pflèger C., Guillou G., Mornet F., Blanchard G.F. (2011) Trophic importance of diatoms in an intertidal Zostera noltii seagrass bed: evidence from stable isotope and fatty acid analyses. Estuarine, Coastal and Shelf Science, 92, 140-153.

Lepoint G., Nyssen F., Gobert S., Dauby P., Bouquegneau J.M. (2000) Relative impact of a seagrass bed and its ajacent epilithic algal community in consumer diets. Marine Biology, 136, 513-518.

Lepoint G., Cox A.S., Dauby P., Poulicek M., Gobert S. (2006) Food sources of two detritivore amphipods associated with the seagrass Posidonia oceanica leaf litter. Marine Biology Research, 2, 355-365.

Mazzella L., Russo G.F. (1989) Grazing effect of two Gibbula species (Mollusca, Archaeogastropoda) on the epiphytic community of Posidonia oceanica leaves. Aquatic Botany, 35, 353-373.
Mazzella L., Scipione M.B., Buia M.C. (1989) Spatio-temporal distribution of algal and animal communities in a Posidonia oceanica meadow. Marine Ecology, 10, 107-129.

Mazzella L., Buia M.C., Gambi M.C., Lorenti M., Russo G.F., Scipione M.B., Zupo V. (1992) Plant-animal trophic relationships in the Posidonia oceanica ecosystem of the Mediterranean Sea: a review. In: John D.M., Hawkins S.J., Price J.H. (Eds), Plant-Animal Interactions in the Marine Benthos. Clarendon Press, Oxford: 165-187.

Michel L. (2011) Multidisciplinary study of trophic diversity and functional role of amphipod crustaceans associated to Posidonia oceanica meadows. Ph.D. thesis, University of Liège, Liège, Belgium.

Michel L., Lepoint G., Dauby P., Sturaro N. (2010) Sampling methods for amphipods of Posidonia oceanica meadows: a comparative study. Crustaceana, 83, 39-47.

Parnell A.C., Inger R., Bearhop S., Jackson A.L. (2010) Source partitioning using stable isotopes: coping with too much variation. PLoS One, 5, e9672.

Pergent G., Rico-Raimondino V., Pergent-Martini C. (1997) Fate of primary production in Posidonia oceanica meadows of the Mediterranean. Aquatic Botany, 59, 307-321.

Prado P., Tomas F., Alcoverro T., Romero J. (2007) Extensive direct measurements of Posidonia oceanica defoliation confirm the importance of herbivory in temperate seagrass meadows. Marine Ecology Progress Series, 340, 63-71.

Ruffo S., Bellan-Santini D., Karaman G., Krapp-Schickel G., Ledoyer M. (1993) Part 3: Gammaridea (Melphidippidae to Talitridae), Ingolfiellidea, Caprellidea. In: Ruffo S. (Ed.), The Amphipoda of the Mediterranean. Imprimerie Nationale de Monaco, Monaco: 577-813.

Sánchez-Jerez P., Barberá-Cebrián C., Ramos-Esplá A.A. (1999) Daily vertical migrations in the epifauna associated with Posidonia oceanica meadows. Journal of the Marine Biological Association of the United Kingdom, 79, 971-977.

Valentine J.F., Duffy J.E. (2006) The central role of grazing in seagrass ecology. In: Larkum A.W.D., Orth R.J., Duarte C.M. (Eds), Seagrasses: Biology, Ecology and Conservation. Springer, Berlin, Germany: 463-501.

Vizzini S. (2009) Analysis of the trophic role of Mediterranean seagrasses in marine coastal ecosystems: a review. Botanica Marina, 52, 383-393.

Vizzini S., Sarà G., Michener R.H., Mazzola A. (2002) The role and contribution of the seagrass Posidonia oceanica (L.) Delile organic matter for secondary consumers as revealed by carbon and nitrogen stable isotope analysis. Acta Oecologica, 23, 277-285. 